\title{
A GLIMPSE TO THE WORKING CONDITIONS IN THE TWENTIES AND THIRTIES IN ECUADOR
}

\author{
UN VISTAZO A LAS CONDICIONES DE TRABAJO EN LOS AÑOS VEINTE Y TREINTA EN EL ECUADOR.
}

Bryan Josué Naranjo Navas ${ }^{1}$

Christian Paúl Naranjo Navas ${ }^{2}$

\section{Resumen}

This article develops three topics that are closely related: internal consumption, working conditions, and price index in Ecuador in relation to the Latin American region. With regard to working conditions, these have been contextualized taking into account labor laws, the social security system, and the development of the establishment of the minimum wage. After reviewing the labor conditions, making use of the bulletins of the Central Bank of Ecuador, the price index for the decade studied will be reconstructed.

\section{Palabras clave}

Ecuador, labor conditions, social security system, minimum wage, economic history

\section{Abstract}

En este artículo se desarrolla tres temas que están estrechamente relacionados: consumo interno, condiciones laborales, e índice de precios en Ecuador con relación a la región de América Latina. Con relación a las condiciones laborales, éstas se han contextualizado tomando en cuenta las leyes laborales, el sistema de seguridad social, y el desarrollo del establecimiento del salario mínimo. Después de revisar las condiciones laborales, haciendo uso de los boletines del Banco Central del Ecuador, se reconstruirá el índice de precios para la década estudiada.

\section{Keywords}

Ecuador, condiciones laborales, sistema de seguridad social, salario mínimo, historia económica

\footnotetext{
${ }^{1}$ Universidad San Francisco de Quito (Ecuador). Correo electrónico: eldestinobryan@hotmail.com.

2 Universidad Nacional de Chimborazo (Ecuador). Correo electrónico: cnaranjo@unach.edu.ec.
} 


\section{Introduction}

To be able to analyze the working conditions in Ecuador during the decades of the twenties and thirties, it is needed to consider the political and economic environment that developed in Ecuador and in the Latin America region. During these decades, some important events occurred, events that changed the political and economic perspectives. Within the first decades of the twentieth century, a period called as Plutocracy, the government and private banks made political and economic decisions based on their mutual interests. In July 1925, the Julian Revolution overthrew the government of the President Córdova, and found the Central Bank of Ecuador in 1927 with the gold reserves of some private banks (Naranjo Navas, 2017).

The Julian Revolution chose Isidro Ayora as the President of Ecuador. Ayora had to face the critical economic situation that was known as the Great Depression. This crisis obliged the government to leave the gold standard, which created increasing inflation rates. The economic crisis caused a decade lasting political instability, with fourteen presidents during the decade of the thirties. Thus, within these two decades, some profound political and economic events that pictured the context of the working conditions took place.

When the Great Depression hit the Latin America region from 1929 to 1934, industries and laborers faced a twofold situation. On the one hand, taking into consideration that most of the countries' monetary system was based on the gold standard, the money offer reduced, which, in return, obligated people to acquire less products and paid for less amount of services, making industries lower the prices of their products and services in order to keep their competitiveness given the new market conditions (Drinot \& Knight, 2014). On the other hand, as industries sold less, their production costs ought to be reduced as well, finding two possible solutions: the diminution of salaries, or the decrease of the number of workers (Arnaut, 2010). Because of certain law restrictions, producers preferred to decrease the number of workers, increasing, in this way, the percentage of unemployment.

Within the thirties, the workers received several important benefits: eviction, compensation for untimely separation, maximum duration of work and rest, prohibition to work under fourteen years. This current legal context can be presumed as a generalized work environment in public works, however, it is not a generalized environment in the private sector. No reports have been found that evidence the applicability of labor laws, which is understandable given the high rate of informality, with most of the population living in community barter systems or in labor systems based on huasipungo.
As part of working conditions is the establishment of the minimum wage, which rules in Ecuador as a general and mandatory rule from 1936. During the decade of the thirties, some Latin American countries implemented political and legal processes for the establishment of the minimum wage. A trend can be noted in the establishment of minimum wages: the minimum wage was not unique but presented an upper limit and a lower one depending on zones and regions.

The research method used in this article is the Historicalcomparative method, which intends to establish certain similarities or differences within a certain phenomenon, considering different places, political, economic or social structures. Also, this article develops three topics that are thoroughly related: internal consumption, working conditions, and price index in Ecuador in relation to the Latin American region. With regard to working conditions, these have been contextualized taking into account labor laws, the social security system, and the development of the establishment of the minimum wage. After reviewing the labor conditions, making use of the bulletins of the Central Bank of Ecuador, the price index for the decade studied will be reconstructed.

\section{Internal Consumption}

Given the composition of the Ecuadorian population, it is known that at least half the population was indigenous, which led a completely sedentary life, feeding only on grains or tubers that gives them their 'huasipungo' and dressing in the simple fabrics they produce by themselves or their neighboring weavers, in exchange for the milk of their goats or cows or the wool of their sheep, or of the meat of their poultry (Central Bank of Ecuador, 1940). According to the same source, this part of the population is outside the internal commerce of consumption because they are producers and consumers of the products that they cultivated or exchanged.

About a quarter of the population is composed of wageearning workers or peasants who barely participated in the national trade, and the rest is made up of public employees, merchants, industrialists and rentier owners, who participated actively in the national trade. It is also to consider the limited purchasing power of the inhabitants in Ecuador, with a population close to 2 million inhabitants, their purchasing power was low and did not exceed that of an entire developed country of 200,000 (Feiker, 1931) inhabitants. Feiker (1931) estimates that most of the Ecuadorian population was related to agriculture.

Some agricultural products that include sugar, cotton, tobacco, corn, rice, potatoes, and other products such as bananas, pineapples, oranges, lemons, and other fruits, all these products were consumed almost entirely within 
the national territory (Stevens, 1940). The products with the highest internal consumption in Guayaquil, the main coastal city, were the upper top cocoa, coffee, rice, sugar, tagua and mountain hides. In Quito, the main products were rice, peas, lentils, barley, coffee, wheat, morocho, beans, potatoes and corn (Central Bank of Ecuador, 1930). Below are the 1928 and 1929 prices, presented by months, of the most important products in the Quito and Guayaquil markets. The prices of the main products of these markets were collected by hand, daily, by the Ministry of Finance, and then published in the bulletins of the Central Bank of Ecuador.

Table 1. Prices in the Plaza de Guayaquil, in Sucres, 100 pounds quintal

\begin{tabular}{|c|c|c|c|c|c|c|c|c|}
\hline \multirow{2}{*}{ Products } & \multicolumn{2}{|c|}{ January } & \multicolumn{2}{|c|}{ February } & \multicolumn{2}{|c|}{ March } & \multicolumn{2}{|c|}{ April } \\
\hline & 1928 & 1929 & 1928 & 1929 & 1928 & 1929 & 1928 & 1929 \\
\hline Cocoa Arriba Superior & 48 & 48 & 62 & 57 & 71 & 57 & 64 & 54 \\
\hline Coffee & 85 & 90 & 89 & 90 & 85 & 90 & 85 & 93 \\
\hline Rice & 18 & 17 & 16 & 17 & 13 & 17 & 14 & 15 \\
\hline Sugar & 22 & 21 & 22 & 21 & 22 & 21 & 22 & 21 \\
\hline Tagua & 9,50 & 7 & 7 & 7 & 7 & 7 & 7 & 7 \\
\hline \multirow[t]{3}{*}{ Leather } & 82 & 37 & 72 & 42 & 72 & 42 & 75 & 47 \\
\hline & \multicolumn{2}{|c|}{ May } & \multicolumn{2}{|c|}{ June } & \multicolumn{2}{|c|}{ July } & \multicolumn{2}{|c|}{ August } \\
\hline & 1928 & 1929 & 1928 & 1929 & 1928 & 1929 & 1928 & 1929 \\
\hline Cocoa Arriba Superior & 66,5 & 54 & 62 & 62 & 60 & 65 & 48 & 64 \\
\hline Coffee & 92 & 92 & 94 & 85 & 93 & 74 & 90 & 75 \\
\hline Rice & 13 & 15 & 13 & 17 & 12 & 18 & 11 & 18,5 \\
\hline Sugar & 22 & 22 & 22 & 21 & 22 & 21 & 21 & 21 \\
\hline Tagua & 7 & 6 & 8 & 6 & 8 & 7 & 7 & 7 \\
\hline \multirow[t]{3}{*}{ Leather } & 72 & 37 & 72 & 37 & & 42 & 82 & 42 \\
\hline & \multicolumn{2}{|c|}{ Sepember } & \multicolumn{2}{|c|}{ October } & \multicolumn{2}{|c|}{ November } & \multicolumn{2}{|c|}{ December } \\
\hline & 1928 & 1929 & 1928 & 1929 & 1928 & 1929 & 1928 & 1929 \\
\hline Cocoa Arriba Superior & 47,5 & 66 & 45,5 & 74,5 & 44,5 & 54 & 46 & 59 \\
\hline Coffee & 90 & 74 & 90 & 55 & 83 & 61 & 83 & 50 \\
\hline Rice & 12 & 18,5 & 13 & 16,5 & 18 & 18,5 & 16,5 & 19 \\
\hline Sugar & 21 & 21 & 21 & 21 & 21,3 & 21 & 21 & 21 \\
\hline Tagua & 7 & 7 & 6 & 7 & 7 & 7 & 7 & 6,5 \\
\hline Leather & 95 & 52 & 82 & 32 & 82 & 12 & 72 & 20 \\
\hline
\end{tabular}

Source: Banco Central del Ecuador, october 1930.

Table 2. Prices in the Plaza de Quito, in sucres, 100 pounds quintal

\begin{tabular}{|c|c|c|c|c|c|c|c|c|}
\hline \multirow{2}{*}{ Products } & \multicolumn{2}{|c|}{ January } & \multicolumn{2}{c|}{ February } & \multicolumn{2}{c|}{ March } & \multicolumn{2}{|c|}{ April } \\
\cline { 2 - 9 } & 1927 & 1928 & 1927 & 1928 & 1927 & 1928 & 1927 & 1928 \\
\hline Rice & - & 21,75 & 32 & 21 & 32,5 & 20,5 & 34,5 & 17 \\
\hline Peas & - & 15,5 & 21 & 16,5 & 21,5 & 17 & 21 & 16 \\
\hline Lentil & - & 28 & 37 & 26,25 & 38 & 27 & 37,9 & 27 \\
\hline Barley & - & 4,5 & 13,5 & 5 & 13,5 & 5 & 12,5 & 4,75 \\
\hline Coffee & - & 99 & 100 & 84 & 100 & 93 & 97,5 & 93 \\
\hline Wheat & - & 14,45 & 17,17 & 14,45 & 16,97 & 13,58 & 16,78 & 13,58 \\
\hline Morocho & - & 6 & 17 & 6 & 18 & 5,7 & 17,5 & 5,25 \\
\hline Frejol & - & 17,5 & 28,5 & 15 & 27,5 & 15,35 & 25,5 & 15 \\
\hline
\end{tabular}

\begin{tabular}{|c|c|c|c|c|c|c|c|c|}
\hline Potatoes & - & 4,8 & 6,5 & 4,29 & 6,65 & 4,29 & 6,25 & 6,07 \\
\hline Corn & - & 4,92 & 16 & 5,32 & 17,5 & 4,52 & 17,52 & 3,95 \\
\hline \multirow{2}{*}{} & \multicolumn{2}{|c}{ May } & \multicolumn{2}{|c|}{ June } & \multicolumn{3}{|c|}{ July } & \multicolumn{2}{|c|}{ August } \\
\cline { 2 - 11 } & 1927 & 1928 & 1927 & 1928 & 1927 & 1928 & 1927 & 1928 \\
\hline Rice & 32,75 & 15,5 & 24 & 14 & 26,5 & 15 & 34 & 14,75 \\
\hline Peas & 21,5 & 16 & 19,5 & 15,75 & 22 & 14,5 & 20,5 & 14 \\
\hline Lentil & 37 & 26,7 & 27,5 & 27,1 & 32,5 & 27,25 & 31,5 & 25 \\
\hline Barley & 10,35 & 4,65 & 5 & 4,75 & 6,5 & 3,8 & 5,25 & 4 \\
\hline Coffee & 96,5 & 89 & 96 & 89 & 97,5 & 96,5 & 100 & 98 \\
\hline Wheat & 16,35 & 13,32 & 16,56 & 13,04 & 15,37 & 13,32 & 16,49 & 13,52 \\
\hline Morocho & 17,25 & 5,1 & 13 & 4,5 & 12,25 & 4,45 & 9,5 & 4,4 \\
\hline Frejol & 25 & 13,84 & 22 & 13,75 & 20 & 13,5 & 14,25 & 12,5 \\
\hline Potatoes & 5,05 & 4,97 & 4,8 & 5,37 & 5,6 & 5,75 & 5,10 & 8,25 \\
\hline Corn & 6,32 & 4 & 12,37 & 4,42 & 9,05 & 4 & 7,22 & 4,45 \\
\hline \multirow{2}{*}{ September } & \multicolumn{2}{|c|}{ October } & November & December \\
\cline { 2 - 12 } & 1927 & 1928 & 1927 & 1928 & 1927 & 1928 & 1927 & 1928 \\
\hline Rice & 23 & 14,5 & - & 21,78 & - & 21,5 & - & 21 \\
\hline Peas & 20,5 & 14 & - & 17,5 & - & 16 & - & 16 \\
\hline Lentil & 32,5 & 25 & - & 27 & - & 24 & - & 28 \\
\hline Barley & 4,75 & 4,25 & - & 4,25 & - & 4,87 & - & 5 \\
\hline Coffee & 95 & 98 & - & 82 & - & 86 & - & 94 \\
\hline Wheat & 16,52 & 13,33 & - & 14,77 & - & 14,89 & - & 15,21 \\
\hline Morocho & 8,5 & 4,45 & - & 7,37 & - & 5,5 & - & 6,25 \\
\hline Frejol & 13,5 & 12 & - & 13,28 & - & 15,5 & - & 15 \\
\hline Potatoes & 4,9 & 8,7 & - & 5,05 & - & 5,75 & - & 5,8 \\
\hline Corn & 6,65 & 5,75 & - & 5,42 & - & 5,27 & - & 4,92 \\
\hline
\end{tabular}

Source: Banco Central del Ecuador, october 1930.

\section{Labor conditions}

The working conditions in the Ecuadorian context, it is important to understand the context of work in the decade from 1927 to 1937, are studied through three important topics, namely: the current labor laws, the social security system, and the establishment of the minimum salary. The current labor laws build the legal landscape around work; the social security system shows a clear context of the labor benefits in health and pension matters; and the minimum wage establishes minimum wages indispensable for the subsistence of a person. The evolution, legality and legitimacy of the minimum wage will correspond to the analysis of the following section.

With regard to the legal context, before 1927, some legislative provisions pertinent to labor conditions can be found. Thus, among the most important we find those described below. The Penal Code of 1906, in force in the 1920 s and 30s, instituted a system of labor protection for workers, punishing with prison or fines the salary reductions (Article 298). On September 11, 1916, some work rules were decreed, "by which the hours and days of labor are fixed, in eight the first and six the second, per week" (Albornoz, 1931, p. 52). In the same report it is mentioned that, in 1921, the "Law on pecuniary 
compensation to the worker or day laborer, due to work accidents" was promulgated (Albornoz, 1931, p. 53). On July 13, 1925, the Social Welfare and Labor Section was created for the first time and on July 13, 1926, the General Labor Inspectorate was created.

As of 1927 several reforms and new laws to the labor situation are found which are described below. On March 4, 1927, the Labor Accident Prevention Law was passed, on March 8, the Retirement Law, Montepío Civil, Savings and Cooperative was enacted. On October 7, 1928, six laws were promulgated, namely: Law on Individual Labor Contract; Law of Maximum Duration of the Weekly Work and Rest Day; Law on Work of Women and Children, and Protection of Motherhood; Eviction Law; Law on Liability for Work Accidents and Procedures Law for Actions Coming from Work. (Albornoz, 1931, pp. 5862).

The Law on individual work contracts defines the legal concept of employer, eviction cases are foreseen; and compensation for untimely separation. The Law on maximum duration of working hours and weekly rest sets the mandatory work of every worker, private and public employee in eight hours a day and six days a week; In addition, for public employees, rest days are established on the days decreed as civic days, determines the overtime payment; and, it indicates the daily rest that divides the working day in two. The law of eviction of the work indicates penalties for cases of untimely separations and fixes the terms of eviction and indemnities. The Law on Workers' Compensation Liability regulates compensation according to the severity of the harm caused by the accident (Albornoz, 1931, pp. 63-65).

The Law on the work of women and minors and the protection of maternity prohibits work for minors under fourteen years, establishes the obligation of employers to attend the primary education of workers under eighteen years of age, and is established as the maximum labor forty-eight hours a week to children under eighteen. With regard to women, the prohibition of night work, subsidized breaks during the previous three weeks and the three weeks following childbirth is established (Albornoz, 1931, p. 64).

This current legal context can be presumed as a generalized work environment in public works, however, it is not a generalized environment in the private sector. No reports have been found that report on the applicability of labor laws, which is understandable given the high rate of informality, with most of the population living in community barter systems or in labor systems based on huasipungo. Thus, with the labor legality system in force to date, it is likely that it has been applied throughout the public sector and to a lesser extent to the industrial sector. However, the application of labor legality with workers in workshops, day laborers, servants and, in general, throughout the informal sector is doubtful.

Those who lived in huasipungos were "destitute of land, homeless, without belongings of any kind, they commit themselves, sometimes for all their lives, for a minimum amount whose debt is never extinguished" (Albornoz, 1931, p. 47). Those farmers who lived on rented land pay the rent with the work of the land, that is, with what they cultivated and, sometimes, with monetary species. Therefore, the labor context in many of the peasants did not correspond to the one outlined in the labor laws.

The right to strikes and work risks are also considered. With respect to strikes, on July 31, 1936, the Strikes Law was promulgated, in which it was mentioned that in order to benefit from this right, workers have to exhaust the means of institutional complaints, "they must address the employer's his requests, to which $51 \%$ of the workers of the factory have to adhere ... and can only declare a strike if, three days after receiving the aforementioned statement, the employer is silent or replies negatively" (Guerrero, 1937: p 25).

The Labor Accident Law was enacted in 1928, and was divided into two, namely: work accidents and occupational diseases. The law also prescribes compensation in case of partial disability, "the victim has the right to be compensated with an amount equivalent to two years of wages" (Guerrero, 1937, p. 22).

With respect to the social security system, this was founded in 1928 as the "Pension Fund, which established mainly the benefits of retirement, civilian and mortuary fund in favor of civil and military civil servants" (Instituto Nacional de Previsión, 1938, p. i). The benefits of the Pension Fund included medical assistance, life annuities for total disability, retirements and refunds of all contributions. Medical assistance to workers who suffered from illnesses contracted in the performance of their work, or outside of them; disability annuities based on a monthly contribution to the Caja of 5\%, "the cashier will grant an annual annuity of \$ 864" (Instituto Nacional de Previsión, 1938, p. 6); retirements when the member was seventy-five years old, or when the member retired with twenty or more years of contributions; refunds of all contributions, "if the worker is unemployed, or withdraws from the Fund for any other legal reason, his contributions are returned intact" (Instituto Nacional de Previsión, 1938, p. 7).

\section{Minimum salary}

The establishment of the minimum wage, which governs in Ecuador as a general and mandatory rule from 1936, is part of working conditions, as it is said next: "another 
achievement of significance, is the relative minimum wage. The lack of legal fixation of the same, was a void that had to be filled urgently ... after lengthy investigations it was possible to point out the minimum wage in a daily sucre in the mountain region, and two, in the coast region" (Guerrero, 1937, pp. 22- 2. 3).

Despite the establishment of the minimum wage in Ecuador, it did not ensure the payment of the same to the entire economically active population, composed mostly of informal jobs. This is the case of the peasants, "many of them do not receive any salary in cash, rewarding their services with the land they occupy; others, according to the relations and agreements of the rustic estates, in the mountains, receive salaries that fluctuate from twenty to fifty cents, and in warm regions, from eighty cents to two and three sucres "(Moreno, 1934, p. 73).

The fixing of the minimum wage aims to ensure the minimum necessary for the subsistence of workers and therefore the minimum wage provides important information to generate a lower limit necessary for the subsistence of workers and their families. Thus, it can be considered that any person with a family income, per person, less than 25 sucres were part of the poor class.

\section{Latin America}

During the decade of the thirties, some Latin American countries implemented political and legal processes for the establishment of the minimum wage. The countries that implemented minimum wage scales took into account a variety of elements, such as the opinions and suggestions of the public sector, the geographical difficulties and demands of the labor sectors. From the data obtained in the countries studied, a trend can be noted in the establishment of minimum wages: the minimum wage was not unique, but presented an upper and a lower limit.

In the decade of the thirties, some Latin American countries implemented political and legal processes for the establishment of the minimum wage, thus, Brazil, Mexico, Peru and Uruguay established at the constitutional level the need to establish a minimum wage (Owen, 1938, pp. 323-336). However, not all nations immediately implemented a system of legality to apply the constitutional norm.

Other nations, such as Argentina, Brazil, Chile, Costa Rica, Cuba and Ecuador, took the initiative to form multi-section commissions for the establishment of minimum wages. In the decade of the thirties, in US dollars, Argentina had a minimum wage that varied from 80.65 to 0.87 ; Bolivia, from 72.53 to 38.85 ; Brazil, from 72.53 to 38.85; Chile, from 15.72 to 4.24; and, Ecuador, from 4.77 to 1.17. Based on the report by Eugene Owen
(1938), the legal processes in Argentina, Bolivia, Brazil and Chile, and the minimum wage tables in each of these countries are briefly described below.

\section{Argentina}

In the case of Argentina, minimum wages were established under the regulation of April 15, 1935, the date on which the minimum wage was enacted for the tailoring sector, while June 9, 1937 for the footwear industry. In the case of the textile sector, a minimum wage of 11 pesos is established for those who make wool raincoats, while it is 0.12 pesos for those who are engaged in short underpants. On the other hand, the Owen report (1938) refers to a bricklayers' strike that put pressure on the resolution of January 24, 1936 on the minimum wage for a working day of eight hours a day: foremen, 6.40 pesos; assistant foreman, 5.20 pesos; pawns, 4.50 pesos.

Finally, the minimum wages of public workers were promulgated in the decree of September 28, 1934, dividing the Republic of Argentina into five zones, each with its own daily and monthly minimum wages. Minimum wages varied from 90 pesos for zone E to 160 pesos for zone $\mathrm{A}$, and the daily minimum varied from 3.60 pesos to 6.40 pesos respectively.

To understand the minimum wages established in Argentina at the Latin American level, it is necessary to obtain its value in dollars through the exchange rate of the decade. Thus, in 1937, the monthly minimum wage in US dollars, in free exchange, is divided into three sectors: tailoring, which varies from 80.65 (woolen raincoat tailoring) to 0.87 (short briefs); masonry, the monthly minimum wage varies from 53.29 (foremen) to 32.99 (laborers); finally, in the public sector, the monthly minimum wage ranges from 53.29 (zone a) to 26.39 (zone e). Tailoring jobs as the masonry sector has only the minimum daily wage. To obtain the monthly salary, the daily minimum has been multiplied by 25 , given that the salaries of the public sector are referenced 25 days a month. However, it is important to mention that the number of days worked per month may vary according to the sector.

Table 3. Exchange rate: Argentine pesos in cents, 19291937

\begin{tabular}{|c|c|c|c|c|c|c|c|c|c|}
\hline & 1929 & 1930 & 1931 & 1932 & 1933 & 1934 & 1935 & 1936 & 1937 \\
\hline $\begin{array}{c}\text { Official } \\
\text { change }\end{array}$ & 40,92 & 33,24 & 25,72 & 25,78 & 33,35 & 32,95 & 32,35 & 32,72 & 33,31 \\
\hline $\begin{array}{c}\text { Free } \\
\text { change }\end{array}$ & - & - & - & - & - & 25,04 & 27,25 & 29,85 & 29,33 \\
\hline
\end{tabular}

Source: Dirección Nacional de Estadística, 1944, p. 30 
Table 4. Minimum wages in Argentina in US dollars, 1935-1937

\begin{tabular}{|c|c|c|c|c|}
\hline \multirow{2}{*}{\multicolumn{2}{|c|}{$\begin{array}{l}\text { Work place } \\
\text { dayly- monthly }\end{array}$}} & 1935 & 1936 & 1937 \\
\hline & & dayly- monthly & dayly- monthly & dayly- monthly \\
\hline \multirow{2}{*}{$\begin{array}{l}\text { Tailoring Wool } \\
\text { Trench Coats }\end{array}$} & $\begin{array}{l}\text { Official } \\
\text { change }\end{array}$ & $3,55-88,96$ & $3,59-89,98$ & $3,66-91,60$ \\
\hline & Free change & $2,99-74,99$ & $3,28-82,08$ & $3,22-80,65$ \\
\hline \multirow{2}{*}{ Short underpants } & $\begin{array}{l}\text { Official } \\
\text { change }\end{array}$ & $0,038-0,97$ & $0,039-0,98$ & $0,039-0,99$ \\
\hline & Free change & $0,032-0,81$ & $0,035-0,89$ & $0,035-0,87$ \\
\hline \multirow{2}{*}{ Foreman } & $\begin{array}{l}\text { Official } \\
\text { change }\end{array}$ & \multirow[t]{2}{*}{ - } & $2,09-52,35$ & $2,13-53,29$ \\
\hline & Free change & & $1,91-47,76$ & $1,87-46,92$ \\
\hline \multirow{2}{*}{ Foreman Assistants } & $\begin{array}{l}\text { Official } \\
\text { change }\end{array}$ & \multirow[t]{2}{*}{ - } & $1,70-42,53$ & $1,73-43,30$ \\
\hline & Free change & & $1,55-38,80$ & $1,52-38,12$ \\
\hline \multirow{2}{*}{ Pawns } & $\begin{array}{l}\text { Official } \\
\text { change }\end{array}$ & \multirow[t]{2}{*}{ - } & $1,47-36,81$ & $1,49-37,47$ \\
\hline & Free change & & $1,34-33,85$ & $1,31-32,99$ \\
\hline \multirow{2}{*}{$\begin{array}{l}\text { Public workers. } \\
\text { Zone A }\end{array}$} & $\begin{array}{l}\text { Official } \\
\text { change }\end{array}$ & $2,07-51,76$ & $2,09-52,35$ & $2,13-53,29$ \\
\hline & Free change & $1,74-43,60$ & $1,91-47,76$ & $1,87-46,92$ \\
\hline \multirow{2}{*}{$\begin{array}{l}\text { Public workers. } \\
\text { Zone E }\end{array}$} & $\begin{array}{l}\text { Official } \\
\text { change }\end{array}$ & $1,16-29,11$ & $1,17-29,44$ & $1,19-29,97$ \\
\hline & Free change & $0,98-24,52$ & $1,07-26,86$ & $1,05-26,39$ \\
\hline
\end{tabular}

Source: authors' creation. Data come from: Owen, 1938, p. 325.

\section{Bolivia}

On June 27, 1936, the Bolivian government decreed minimum wages for the public and private sectors through percentage increases depending on the sector and the income recorded. Thus, for example, for those with less than 100 bolivianos per month, the salary was increased by $120 \%$. For those who received 1201 bolivianos or more per month, they obtained a net increase of 780 bolivianos. Daily salaries of up to 1 Bolivian increased by $120 \%$, while domestic workers who received up to 5 bolivianos per day obtained an increase of 80\% (Owen, 1938, p. 326).

In 1937 the minimum wage was established in the following way: for workers in commercial and industrial sectors, without distinction of sex, 140 Bolivians; for older adults, 5 bolivianos per day; for minors between 14 and 18 years old, 3 Bolivians. The minimum wage did not include the agricultural work of industries with assets less than 50,000 bolivianos. In 1937, the minimum monthly salary in US dollars, in exchange for banking, is divided into three sectors: in the commercial and industrial sector, the minimum wage is 72.53 ; older adults have a minimum wage of 64.76; and, minors had a minimum wage of 38.85 .
Table 5. Exchange rate: Bolivians in cents, 1929-1937

\begin{tabular}{|c|c|c|c|c|c|c|c|c|c|}
\hline & 1929 & 1930 & 1931 & 1932 & 1933 & 1934 & 1935 & 1936 & 1937 \\
\hline $\begin{array}{l}\text { Official } \\
\text { change }\end{array}$ & 36,00 & 35,21 & 35,36 & 18,32 & 25,50 & 24,00 & 23,56 & 9,63 & - \\
\hline $\begin{array}{l}\text { Banking } \\
\text { change }\end{array}$ & - & - & - & - & - & - & - & 55,87 & 51,81 \\
\hline
\end{tabular}

Table 6. Minimum wages in Bolivia, in US dollars, 1937

\begin{tabular}{|l|l|}
\hline Work place & Dayly- monthly \\
\hline Commercial and Industrial Sectors & $2,90-72,53$ \\
\hline Older adults & $2,59-64,76$ \\
\hline Children between 14 and 18 years old & $1,55-38,85$ \\
\hline
\end{tabular}

Source: authors' creation. Data come from: Owen, 1938, p. 326

\section{Brazil}

In the Constitution of November 10,1937, it is observed the need to establish a "minimum wage capable of satisfying, according to each region, the normal needs of work" (Owen, 1938, p. 326). Commissions were established to propose salaries for each region and salaries would finally be established through an executive decree. Minors who work as apprentices would receive half the salary of an adult, while those who work in unhealthy conditions would receive a salary and a half. Any employment contract with a salary below the stipulated minimum wage would be null, and the worker could claim the difference at any time.

The increase in salaries of federal civilian personnel was made through a law of January 13, 1936. Salaries with an income of less than 150 milreis, were raised to 200 milreis, salaries between 150 and 1500 milreis increased $40 \%$ for first 500 milreis, then $20 \%$ for each cent or fraction up to 1000 milreis, and $10 \%$ for each cent up to 1500 milreis. Those salaries between 1500 and 2500 milreis had a net increase of 300 milreis, from 2,500 to 3,000 , an increase of 250; from 3000 to 4000 , an increase of 200 . In 1936, the monthly minimum wage in US dollars, in free exchange, is divided according to the income prior to 1936 and according to each region. The lowest minimum wage is \$ 17.50 while the highest is $\$ 278.40$.

Table 7. Exchange rate: milreis in US cents, 1929-1937

\begin{tabular}{llllllllll}
\hline & 1929 & 1930 & 1931 & 1932 & 1933 & 1934 & 1935 & 1936 & 1937 \\
\hline Official change & 11,29 & 9,61 & 6,20 & 7,63 & 8,60 & 8,19 & 3,89 & 8,70 & - \\
Free change & - & - & - & - & - & 6,81 & 5,51 & 8,70 & - \\
\hline
\end{tabular}

Source: Dirección Nacional de Estadística, 1944, p. 30 
Table 8. Minimum wages in Brazil, 1936

\begin{tabular}{|l|c|c|}
\hline Before 1936 (Milreis) & 1936 (Milreis) & $\begin{array}{c}\text { Dayly- monthly US } \\
\text { dollars }\end{array}$ \\
\hline Below 150 & 200 & $0,69-17,40$ \\
\hline 150 & 210 & $0,73-18,27$ \\
\hline 1000 & 1100 & $3,82-95,70$ \\
\hline 1500 & 1800 & $6,26-156,60$ \\
\hline 2500 & 2750 & $9,57-239,25$ \\
\hline 3000 & 3200 & $11,13-278,40$ \\
\hline
\end{tabular}

Source: authors' creation. Data come from: Owen, 1938, p. 326

\section{Chile}

The labor code of May 13, 1931, regulated the organization of commissions made up of three representatives of employers and three of workers by industry to enact minimum wages. In case of conflicts, these would be resolved by the Labor Inspector General (Vergara, 2014). The minimum wages of the nitrate industry were enacted on January 8, 1934 and stipulated that the salaries of unmarried workers be 10 pesos per day, and that of married workers or heads of families be 15 pesos per day. The minimum wage for children under 18 , over 65 and for people with physical or mental disabilities can be reduced to $50 \%$ of the minimum wage.

In 1937 the minimum wage was established for the private sector, which could be 300,350 or 400 pesos per month, depending on the cost of living by geographical area. On the other hand, in 1937, the municipality of Santiago approved minimum wages for its workforce, establishing an amount of 12 pesos per day for temporary staff and 13 pesos for permanent staff. From 1934 to 1937, the monthly minimum wage in US dollars, in free exchange, fluctuated from 15.72 (geographical area, 400 pesos in 1937 ) to 4.24 (minors in 1936). Apart from the group of minors, seniors and people with disabilities, the lower limit of the minimum wage is 8.65 (single in 1936).

Table 9. Exchange rate: Chilean pesos in cents, 1929-1937

\begin{tabular}{|l|l|l|l|l|l|l|l|l|l|}
\hline & $\mathbf{1 9 2 9}$ & $\mathbf{1 9 3 0}$ & $\mathbf{1 9 3 1}$ & $\mathbf{1 9 3 2}$ & $\mathbf{1 9 3 3}$ & $\mathbf{1 9 3 4}$ & $\mathbf{1 9 3 5}$ & $\mathbf{1 9 3 6}$ & $\mathbf{1 9 3 7}$ \\
\hline $\begin{array}{l}\text { Official } \\
\text { change }\end{array}$ & 12,09 & 12,10 & 12,07 & 6,03 & 9,60 & 10,24 & 5,09 & 5,17 & 5,17 \\
\hline $\begin{array}{l}\text { Free } \\
\text { change }\end{array}$ & - & - & - & - & 3,80 & 4,19 & 3,81 & 3,46 & 3,93 \\
\hline
\end{tabular}

Source: Dirección Nacional de Estadística, 1944, p. 30

Table 10. Minimum wages in Chile, in US dollars, 1934-1937

\begin{tabular}{|l|l|c|c|c|c|}
\hline \multirow{2}{*}{\begin{tabular}{l} 
Worker \\
\multicolumn{2}{|c|}{ Dayly- monthly }
\end{tabular}} & $\begin{array}{c}1934 \\
\text { Dayly- } \\
\text { monthly }\end{array}$ & $\begin{array}{c}\text { Dayly- } \\
\text { monthly }\end{array}$ & $\begin{array}{c}\text { Dayly- } \\
\text { monthly }\end{array}$ & \multicolumn{1}{|c|}{} \\
\hline \multirow{3}{*}{ Single } & $\begin{array}{l}\text { Official } \\
\text { change }\end{array}$ & $1,02-25,60$ & $0,50-12,72$ & $0,52-12,92$ & $0.52-12,92$ \\
\cline { 2 - 6 } & $\begin{array}{l}\text { Free } \\
\text { change }\end{array}$ & $0,41-10,47$ & $0,38-9,52$ & $0,34-8,65$ & $0,39-9,82$ \\
\hline
\end{tabular}

\begin{tabular}{|c|c|c|c|c|c|}
\hline \multirow{2}{*}{$\begin{array}{l}\text { Married or } \\
\text { heads of } \\
\text { family. }\end{array}$} & $\begin{array}{l}\text { Official } \\
\text { change }\end{array}$ & $1,53-38,40$ & $0,76-19,08$ & $0,77-19,38$ & $0,77-19,08$ \\
\hline & $\begin{array}{l}\text { Free } \\
\text { change }\end{array}$ & $0,62-15,71$ & $0,57-14,28$ & $0,51-12,97$ & $0,58-14,73$ \\
\hline \multirow{2}{*}{$\begin{array}{c}\text { Minors, over } \\
65 \mathrm{~s} \text {, and } \\
\text { people with } \\
\text { disabilities }\end{array}$} & $\begin{array}{l}\text { Official } \\
\text { change }\end{array}$ & $0,51-12,80$ & $0,25-6,36$ & $0,26-6,46$ & $0,26-6,46$ \\
\hline & $\begin{array}{l}\text { Free } \\
\text { change }\end{array}$ & $0,20-5,23$ & $0,19-4,76$ & $0,17-4,24$ & $0,19-4,91$ \\
\hline \multirow{2}{*}{$\begin{array}{l}\text { Minimum } \\
\text { wage by } \\
\text { geographical } \\
\text { area ( } 300 \\
\text { pesos) }\end{array}$} & $\begin{array}{l}\text { Official } \\
\text { change }\end{array}$ & $1,22-30,72$ & $0,61-15,27$ & $0,62-15,51$ & $0,62-15,51$ \\
\hline & $\begin{array}{l}\text { Free } \\
\text { change }\end{array}$ & $0,50-12,57$ & $0,45-11,43$ & $0,41-10,38$ & $0,47-11,79$ \\
\hline \multirow{2}{*}{$\begin{array}{l}\text { Minimum } \\
\text { wage by } \\
\text { geographical } \\
\text { area ( } 350 \\
\text { pesos) }\end{array}$} & $\begin{array}{l}\text { Official } \\
\text { change }\end{array}$ & $1,43-35,84$ & $0,71-17,81$ & $0,72-18,09$ & $0,72-18,09$ \\
\hline & $\begin{array}{l}\text { Free } \\
\text { change }\end{array}$ & $0,58-14,66$ & $0,53-13,33$ & $0,48-12,11$ & $0,55-13,75$ \\
\hline \multirow{2}{*}{$\begin{array}{l}\text { Minimum } \\
\text { wage by } \\
\text { geographical } \\
\text { area (400 } \\
\text { pesos) }\end{array}$} & $\begin{array}{l}\text { Official } \\
\text { change }\end{array}$ & $1,63-40,96$ & $0,81-20,36$ & $0,82-20,68$ & $0,82-20,68$ \\
\hline & $\begin{array}{l}\text { Free } \\
\text { change }\end{array}$ & $0,67-16,76$ & $0,60-15,24$ & $0,55-13,84$ & $0,62-15,72$ \\
\hline
\end{tabular}

Source: authors' creation. Data come from: Owen, 1938, p. 327

\section{Ecuador}

In the Ecuadorian case, there was no minimum wage legally established until 1936, and this non-fixing of a minimum wage became one of the claims in labor disputes. The workers' conflict of the "La Fabrica de la Internacional" factory, included in the Report to the Nation of the Ministry of Government and Social Security of 1934, mentions as one of the initial claims "that the minimum wage of $\$ 1.50$ be established in eight hours of work" (Baquerizo Moreno, 1934: 74). In addition, in the same report, the ministry recommends, through its Minister, Mr. Rodolfo Baquerizo Moreno, that "in order to put into practice the desire to fix wages, it would be convenient for the Honorable Congress to issue a Special Law on the individual, previous the profound study of the diverse zones and customs of the country" (Baquerizo Moreno, 1934, p. 74).

The minimum wage in Ecuador was enacted in 1936 through the Organic Labor Law, which established the legal basis for minimum wages throughout the country (Official Register No. 205, 1936). The first registration was made as an agreement between the parties involved, which is presumed to be an agreement between traders, workers and government. The first calculation of the minimum wage was divided into two sections, namely: manual worker and agricultural worker.

The minimum wages in Ecuador for agricultural workers and private employees were established through an executive decree, of President Federico Páez, on February 4,1937 . The minimum wage for a manual worker over 18 years was one sucre per day in the interior of the country, and two sucres in the coastal region. In Quito, the minimum was one and a half sucre. Agricultural workers over the age of 18 have the right to earn 0.60 sucres in 
the interior and 1.20 sucres in the coastal region. Men under the age of 18 and women of any age who work as manual laborers or agricultural workers would receive a minimum of two thirds of the wages described. This decree did not include domestic workers (Pan American Union, 1937, p. 416).

The minimum wage in Ecuador is divided in relation to labor (manual workers and agricultural workers) and in relation to geographical location (sierra, costa, Quito). Thus, from 1936 to 1937 , the monthly minimum wage in US dollars, in free exchange, fluctuated from 4.77 (manual worker from the coast, 1936) to 1.17 (agricultural worker from the highland region, 1937).

Table 11. Exchange rate: sucres in cents, 1929-1937

\begin{tabular}{|c|c|c|c|c|c|c|c|c|c|}
\hline & 1929 & 1930 & 1931 & 1932 & 1933 & 1934 & 1935 & 1936 & 1937 \\
\hline $\begin{array}{c}\text { Official } \\
\text { change }\end{array}$ & 20,00 & 20,00 & 20,00 & 16,00 & 16,77 & 8,33 & 9,52 & 9,55 & 7,22 \\
\hline
\end{tabular}

Source: Dirección Nacional de Estadística, 1944, p. 30

Table 12. Minimum wages in Ecuador in US dollars, 1936-1937

\begin{tabular}{|l|l|c|c|}
\hline \multirow{2}{*}{\begin{tabular}{l} 
Worker \\
\multicolumn{2}{|c|}{ Dayly- monthly }
\end{tabular}} & Dayly- monthly & Dayly- monthly \\
\cline { 2 - 4 } & Highlands & $0,095-2,38$ & $0,072-1,80$ \\
\cline { 2 - 4 } $\begin{array}{l}\text { Manual } \\
\text { worker }\end{array}$ & Cost & $0,191-4,77$ & $0,144-3,61$ \\
\cline { 2 - 4 } & Quito & $0,14-3,58$ & $0,108-2,70$ \\
\hline $\begin{array}{l}\text { Agricultural } \\
\text { worker }\end{array}$ & Highlands & $0,062-1,55$ & $0,046-1,17$ \\
\cline { 2 - 4 } & Cost & $0,114-2,86$ & $0,086-2,16$ \\
\hline
\end{tabular}

Source: authors' creation. Data come from: Pan American Union, 1937, p. 416

The minimum wages of the Latin American region help to visualize the possible minimum monthly costs for the maintenance of a person. In the Ecuadorian case in the labor sector, these monthly minimums are 25 sucres per month in the interior, 50 sucres in the coastal region, and 37.5 in Quito; in the agricultural sector, 15 sucres per month in the Mountain range, and 30 sucres in the Coast. On average, the monthly minimum for the maintenance of a person was 31.5 sucres. After seeing the working conditions and the evolution of the minimum wage, the price evolution will be studied next through the price index, so that it can be used as a deflator to convert nominal wages, presented in the previous chapter in real wages.

\section{Conclusions}

Working conditions, in Ecuador, at the time of the thirties, workers, legally, received several important benefits: eviction, compensation for untimely separation, maximum duration of work and rest, prohibition to work under fourteen years, etc. This current legal context can be presumed as a generalized work environment in public works, however, it is not a generalized environment in the private sector. No reports have been found that evidence the applicability of labor laws, which is understandable given the high rate of informality, with most of the population living in community barter systems or in labor systems based on huasipungo. Thus, with the system of labor legality in force in the 1920s and 30s, it is likely that it has been applied throughout the public sector and to a lesser extent in the industrial sector.

As part of working conditions is the establishment of the minimum wage, which rules in Ecuador as a general and mandatory rule from 1936. During the decade of the thirties, some Latin American countries implemented political and legal processes for the establishment of the minimum wage. A trend can be noted in the establishment of minimum wages: the minimum wage was not unique but presented an upper limit and a lower one depending on zones and regions.

It is important to note the deflationary trend until 1932 (Ecuador) and 1931 (Latin America) was common to the Latin American region. After these years, some countries show constant fluctuations (Naranjo, 2018). This phenomenon is appreciable taking into account that the Latin American region leaves the gold standard during the thirties (Eichengreen \& Temin, 2000), and therefore the inflationary fluctuations were evident because each government takes measures to increase or decrease the money supply according to its own expertise.

\section{References}

1. Albornoz, M. (1930). Informe del Ministro de Gobierno y Previsión Social. Ministerio de Gobierno y Previsión Social. Quito: Imprenta Nacional.

2. Albornoz, M. (1931). Informe del Ministro de Gobierno y Previsión Social. Ministerio de Gobierno y Previsión Social. Quito: Imprenta Nacional.

3. Arnaut, J. (2010). Understanding the Latin American Gap during the era of Import Substitution. Southern Hemisphere Economic History Summer School.

4. Banco Central del Ecuador. (octubre de 1930). Boletín Mensual. Año IV.

5. Banco Central del Ecuador. (Feb., 1940). Medio Cir- 
culante. No. 150-151, Banco Central del Ecuador, Quito.

6. Baquerizo Moreno, R. (1933). Informe a la Nación. Ministerio de Gobierno y Previsión Social. Quito: Talleres Gráficos Nacionales.

7. Baquerizo Moreno, R. (1934). Informe a la Nación. Ministerio de Gobierno y Previsión Social. Quito: Talleres Gráficos Nacionales.

8. Baquerizo Moreno, R. (1939). Boletín de Informaciones y de Estudios Sociales y Económicos. Informe a la Nación 1933-1934 (5), 117-124.

9. Dirección Nacional de Estadística. (1944). Ecuador en Cifras 1938-1942. Quito, Ecuador: Imprenta del Ministerio de Hacienda.

10. Drinot, P., \& Knight, A. (2014). The Great Depression in Latin America. Durham: Duke University Press.

11. Eichengreen, B., \& Temin, P. (2000). The Gold Standard and the Great Depression. Contemporary European History, 9(2), 183-207.

12. Feiker, F. (1931). Economic and Financial Conditions in Ecuador. U.S. department of Commerce, Bureau of Foreign and Domestic Commerce. Washington: United States Government Printing Office.

13. Guerrero, V. (1937). Informe que el Sr. Teniente Coronel S. Virgilio Guerrero presenta a la H. Asamblea Nacional. Ministerio de Previsión Social, Trabajo, Agricultura, Colonización e Industrias. Quito: Imprenta de la Caja del Seguro de E.P. y O.

14. Instituto Nacional de Previsión. (1939). Antecedentes del Seguro Social. Boletín de informaciones y de estudios sociales y económicos. Publicación Trimestral (1), 3-7.

15. Moreno, M. (1992). Economías y sociedades de plantaciones en el Caribe español, 1860-1930. En L. Bethell, América Latina: economía y sociedad, 1870-
1930. Barcelona: Editorial Crítica, 163-199.

16. Naranjo Navas, C. P. (2017). Evolución de salarios reales en Ecuador durante la Gran Depresión, 19271937. Revista de Historia Económical Journal of Iberian and Latin American Economic History, 1-37.

17. Naranjo Navas, C. P. (2017). Central Bank of Ecuador, 1927: among Dictatorship, Revolution and Crisis. Journal of Evolutionary Studies in Business, 2(1), 128-173.

18. Owen, E. (1938). Minimum Wage Legislation in Latin America. Bureu of Labor Statistics, United States Department of Labor, Bulletin of the Pan American Union, Washington.

19. Pan American Union. (1930). Bulletin of the Pan American Union. International Bureau of the American Republics, Washington.

20. Pan American Union. (1931). Bulletin of the Pan American Union. International Bureau of the American Republics, Washington.

21. Pan American Union. (1937). Ecuador. En Bulletin of the Pan American Union (Vol. XLIV, 120). Washington, USA

22. Pan American Union. (1937). Minimum Wage Legislation in Ecuador. En Bulletin of the Pan American Union (Vol. LXXI, 416). Washington, USA.

23. Pan American Union. (1938). Minimum Wage Legislation in Latin America. Bureu of Labor Statistics, United States Department of Labor, Bulletin of the Pan American Union, Washington.

24. Registro Oficial N.205. (30 de junio de 1936). Decreto Ejecutivo. Quito, Ecuador: Imprenta Nacional.

25. Vergara, A. (2014). Chilean WOrkers and the Great Depression, 1930-1938. En P. Drinot, \& A. Knight, The Great Depression in Latin America (págs. 5180). Durhan: Duke University Press. 